\author{
dr inż. Tomasz POSKROBKO \\ Wydział Ekonomii i Zarządzania, Uniwersytet w Białymstoku \\ e-mail: t.poskrobko@uwb.edu.pl \\ dr inż. Paweł TADEJKO \\ Wydział Informatyki, Politechnika Białostocka \\ e-mail: p.tadejko@pb.uwb.edu.pl
}

DOI: $10.15290 /$ ose.2017.06.90.17

\title{
NARZĘDZIA I TECHNIKI INFORMATYCZNE W PROCESIE KODYFIKACJI WIEDZY ORGANIZACYJNEJ ${ }^{1}$
}

\begin{abstract}
Streszczenie
Głównym celem artykułu jest przegląd najnowszych rozwiązań w dziedzinie narzędzi informatycznych do przetwarzania danych i informacji oraz próba ustalenia możliwości ich zastosowania w procesach zarządzania wiedzą.

Często zarządzanie wiedzą to kluczowe narzędzie w budowaniu przewagi konkurencyjnej i wdrażaniu innowacji. Współczesne przedsiębiorstwa potrzebują coraz bardziej zaawansowanych narzędzi i technologii informatycznych. Publikacja prezentuje kategorie narzędzi używanych na etapie: (1) pozyskiwania wiedzy, (2) dzielenia się wiedzą i (3) wykorzystania wiedzy.

Coraz częściej na etapach zarządzania wiedzą stosuje się inteligentne algorytmy, które, działając dzięki wybranym narzędziom, pozwalają na półautomatyczne lub automatycznie przetwarzanie, a nawet spożytkowanie wiedzy. Obecnie prace naukowców skupiaja się nad wykorzystaniem metod, które określa się mianem machine learning, systemów kognitywnych czy sztucznej inteligencji. Jednak, aby w procesach kodyfikacji mogły być użyte zaawansowane narzędzia, konieczne jest wcześniejsze, dedykowane przetwarzanie danych i informacji z uwzględnieniem wymagań bardziej inteligentnych algorytmów.
\end{abstract}

Słowa kluczowe: zarządzanie wiedzą, technologie informatyczne, kodyfikacja wiedzy, narzędzia, sztuczna inteligencja

1 Badania zostały zrealizowane w ramach pracy S/WI/3/2018 Politechniki Białostockiej i sfinansowane ze środków na naukę MNiSW. 


\section{IT TOOLS AND TECHNIQUES IN THE PROCESS OF CODIFICATION OF ORGANIZATIONAL KNOWLEDGE}

\section{Summary}

The main purpose of the article is to review the latest solutions in the field of IT tools for data and information processing and to try to determine their suitability in the knowledge management process.

Knowledge management is often a key tool in building a competitive advantage and implementing innovations. Modern enterprises need more and more advanced tools and information technologies. The main reason is that today these are no longer individual companies, but consortia, company networks, holdings or clusters. The last decade is also a dynamic development in the use of new IT tools for this purpose. They are used at every stage of knowledge management. The publication presents the results of the analysis of which categories of tools and what effect is used at the stage of: (1) acquiring knowledge, (2) sharing knowledge and (3) using knowledge.

More and more often, intelligent algorithms are used in the knowledge management stages, which by using selected tools allow for semi-automatic or automatic processing and even the use of knowledge. Currently, the work of scientists focuses on the use of methods that are referred to as machine learning, cognitive systems, or finally artificial intelligence. However, in order to be able to use advanced tools in the coding processes, it is necessary to have earlier, dedicated data and information processing taking into account the requirements of more intelligent algorithms.

Key words: knowledge management, information technologies, codification of knowledge, tools, artificial intelligence

JEL Classification: M12, M15, D83

\section{Wstęp}

Najogólniej przez zarządzanie wiedzą rozumie się proces przetwarzania i rozpowszechniania wiedzy w całej organizacji w celu bardziej efektywnej pracy. Zdolność do zarządzania wiedzą ma kluczowe znaczenie w dzisiejszej gospodarce opartej na wiedzy, ponieważ tworzenie i rozpowszechnianie wiedzy jest ważnym czynnikiem konkurencyjności. Coraz częściej wiedza jest uważana za cenny produkt, wbudowany w innowacyjne dobra i usługi (w tym w szczególności w produkty wysokiej technologii) lub pozwalający na podejmowanie celnych decyzji strategicznych w turbulentnym otoczeniu organizacji. Czterdzieści pięć lat temu prawie połowa wszystkich pracowników w krajach uprzemysłowionych wytwarzała lub pomagała wytwarzać produkty materialne, podczas gdy na początku XXI wieku tylko 20\% pracujących było zatrudnionych w przemyśle - resztę stanowili pracownicy umysłowi [Drucker, 1994; Bath, 2000]. Dowodzi to rosnacej roli wiedzy w procesach gospodarczych i tego, że procesy zarządzania wiedzą będą odgrywały coraz istotniejszą rolę w rozwoju gospodarki.

Można wyróżnić dwie zasadnicze strategie zarządzania wiedzą w organizacji. Pierwsza z nich, określana mianem personalizacji wiedzy, główny nacisk kładzie na wiedzę, którą 
dysponują indywidualni pracownicy, jak również komunikację między nimi. Najistotniejszą rolę odgrywaja tutaj bezpośrednie relacje między pracownikami. Technologie informatyczne, takie jak: łączność telefoniczna, wideokonferencje, e-mail, komunikatory itp., są jednak ważnym elementem wspierającym taką strategię. Za ich sprawą eliminuje się bariery w procesie komunikacji związane z odległością między ludźmi czy strefami czasowymi. W tym przypadku zadaniem organizacji jest zachęcanie pracowników do rozwoju ich zasobów wiedzy oraz do dzielenia się nią z innymi, a także stworzenie sieci powiązań między ludźmi i umożliwienie im kontaktów. Druga strategia - kodyfikacji - główny nacisk kładzie na zebranie, przetworzenie i zapewnienie wielokrotnego wykorzystywania posiadanej wiedzy na dużą skalę. Strategia ta opiera się na wykorzystaniu wiedzy jawnej, która jest uzyskiwana, przesyłana i magazynowana dzięki technikom informatycznym.

Zasadniczym celem artykułu jest przegląd najnowszych rozwiązań w dziedzinie maszynowego przetwarzania danych i próba określenia ich przydatności w procesie zarządzania wiedzą ze szczególnym uwzględnieniem strategii kodyfikacji wiedzy.

\section{Zarządzanie wiedzą w organizacji}

Problem zarządzania zasobami szeroko rozumianej wiedzy pojawił się w literaturze naukowej oraz w praktyce gospodarczej u schyłku lat osiemdziesiątych ubiegłego stulecia; pierwotnie jako uczenie się organizacji, następnie jako kreowanie organizacji uczącej się [Senge, 1999], by następnie przekształcić się w nowy, interdyscyplinarny model biznesowy, obejmujący swym zakresem nie tylko nauki ekonomiczne, ale również technologie informacyjne, socjologię i psychologię oraz nowe dziedziny, takie jak bibliometria czy kognitywistka. Obecnie zarządzanie wiedzą wprowadza do teorii i praktyki własne metody $i$ techniki zarządzania, wykorzystując $z$ jednej strony narzędzia znane i stosowane od wielu lat, $z$ drugiej nowoczesne rozwiązania pochodzace przede wszystkim z obszaru informatyki, zarządzania danymi i informacją [Poskrobko, 2015].

Pojęcie procesu zarządzania wiedzą w organizacji do tej pory nie zostało jednoznacznie zoperacjonalizowane. W literaturze istnieje wiele definicji, w których podjęto próbę przedstawienia istoty tego procesu [Kułak, 2010]. Przykładowo można przytoczyć następujące sformułowania:

- zarzadzanie wiedza jest procesem, pray pomocy którego organizacja generuje bogactwo na podstawie swoich intelektualnych lub opartych na wied sy aktywach organizacyjnych [Bukowitz, Williams, 1999];

- proces biznesony, driekei któremu firmy tworza i stosuja w praktyce swoja instytucjonalna lub zbiorowa wiedze [Sarvary, 1999];

- kompozycja ukierunkowanego doswiadcrenia, uisytecznych informacji, fachowego spojrženia i wartości [Prusak, Davenport, 1998];

- systematyczne, jasno - sprecyzowane i przemyślane tworzenie, odnawianie $i$ zastosowanie wiedsy do maksymalizacii efektywności przedsiebiorstwa i osiagania zwrotu z.posiadanych zasobów wiedzy [Wiig, 1993]. 
John P. Girard i Judith L. Girard zebrali ponad sto definicji zarządzania wiedza. Ich zdaniem, wyraźnie widać, że definicje te ewoluuja w czasie, analogicznie jak natura tego zjawiska. Z badań wynika, że na obecnym etapie rozwoju tej dyscypliny trudno jest jednoznacznie stwierdzić, czym jest proces zarządzania wiedza. W ciagu ostatniej dekady odpowiedzialność za ustalenie precyzyjnie stosowanego znaczenia przeniesiono z naukowców na praktyków. Obecnie tworzone przez nich definicje, których celem jest zaspokojenie potrzeb poszczególnych organizacji, zdominowały akademickie podejście do problemu [Girard, Girard, 2015].

Podobnie trudnym, o ile nie trudniejszym, zadaniem jest określenie, czym w zasadzie jest sama wiedza. Pytanie takie stawiali sobie ludzie już u zarania nauki - w starożytności. Epistemologia - jako jedna z najstarszych dziedzin filozofii klasycznej - rozważa naturę takich pojęć, jak: prawda, przekonanie, sąd, spostrzeganie, uzasadnienie czy właśnie wiedza. Jedno z pierwszych odniesień do tego pojęcia znajduje się już w dialogach Platona, który określa wiedzę jako prawdziwe i uzasadnione przekonanie [Pawłowski, 2015]. Współcześni badacze z zakresu nauk o zarządzaniu również próbują zoperacjonalizować pojęcie wiedzy. W publikacjach, dotyczących wiedzy w sensie ekonomicznym, pojawiają się m.in. tacy uczeni, jak: Friedrich von Hayek, Gilbert Probst, Des Tobin, a na gruncie polskim Jerzy Apanowicz, Bogusz Mikuła czy Bazyli Poskrobko.

Zgodnie z modelem kształtowania wiedzy (rysunek 1.), najbardziej podstawowym elementem składowym tego procesu są dane. Według metateorii TOGA Adama M. Gadomskiego [Gadomski, 1993], dane są zdefiniowane jako wszystko to, co jest lub może być przetwarzane umysłowo lub komputerowo. W tym sensie dane są pojęciem relatywnym, istnieją tylko razem z pojęciem przetwarzania danych i moga przyjmować takie postaci, jak: znaki, słowa i sygnały. Kolejny poziom stanowia informacje, które definiuje się jako: wiadomość, wskazówkę, pouczenie albo powiadomienie o czymś, zakomunikowanie czegoś. Jednak na podstawie tej definicji trudno ustalić, czym różni się informacja od danych. Należy więc sprecyzować, że informacje stanowią celowo i kontekstowo uporządkowane dane. W opinii Nonaki i Takeuchiego, informacja dostarcza nowy punkt widzenia w interpretacji zdarzeń albo obiektów, pozwala odkryć nowe, niewidoczne wcześniej, znaczenie, naświetla nowe, nieoczekiwane związki. Stąd jest ona nieodzownym instrumentem odkrywania i budowania wiedzy. Ze zbioru informacji jest kształtowana wiedza. W ujęciu praktycznym można ją określić jako „użytkową informację", która umożliwia podejmowanie trafniejszych decyzji oraz wnosi istotny wkład w proces twórczego myślenia.

W przedsiębiorstwie wykorzystuje się trzy rodzaje wiedzy, tj.: potoczna, zawodowa i naukowa. Wiedza potoczna, zwana także powszechną lub zdroworozsądkowa, to najstarszy rodzaj wiedzy ludzkiej. Zajmuje się ona poznaniem oraz użytkowym wyjaśnieniem i zastosowaniem wszelkich obiektów i zjawisk rzeczywistości w otoczeniu ludzkim. Jest ogólnikowa, nieprecyzyjna, o małej wiarygodności i jednoznaczności. W zasadzie jest skoncentrowana na tych aspektach życia i działalności ludzkiej, które są dostępne prostej i bezpośredniej obserwacji. Przez długi okres rozwoju ludzkości ułatwiała poznanie wartości kulturowych i wykonywanie pracy. Wiedza zawodowa jest to specyficzny 
rodzaj wiedzy związany z wykonywanym zawodem. Wiedzę tę nabywa się w wyniku kształcenia i doświadczenia oraz obserwacji otoczenia, głównie miejsca pracy i sposobu funkcjonowania organizacji. Przydatność wiedzy zawodowej, poza miejscem pracy (szerzej poza branża), na ogół jest ograniczona. Natomiast wiedza naukowa opiera się na procesach myślowych i doświadczeniu praktycznym, obejmuje analizę i ocenę zjawisk obserwowalnych oraz tworzenie myślowych obszarów wirtualnych, może być umiarkowanie inspirowana i koordynowana, jest tworzona z zachowaniem określonych kanonów naukowych oraz metod, technik i narzędzi badawczych [Poskrobko, 2011].

\section{Model kształtowania wiedzy indywidualnej}

\section{RYSUNEK 1 .}

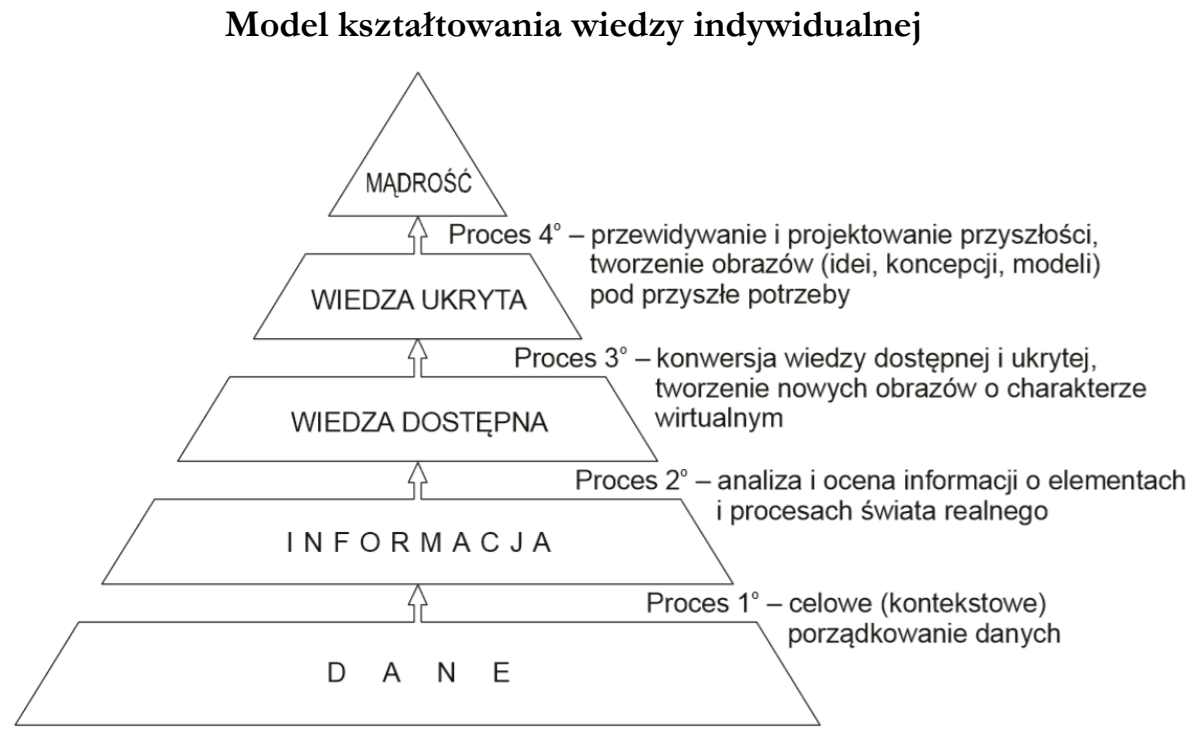

Źródło: [Poskrobko, 2011].

Inny podział wiedzy, niezwykle istotny z punktu widzenia procesów zarządzana w przedsiębiorstwie, dotyczy wiedzy indywidualnej. I. Nonaka i H. Takeuchi [1995], wyróżnili wiedzę jawną i ukrytą (rysunek 2.).

Przez dłuższy czas wiedzę dostępną utożsamiano z wiedzą w ogóle, podczas gdy należy ją rozumieć szerzej - jako informację zawartą w umyśle człowieka, związana głównie z jego świadomościa, która jest: formalnie uporządkowana, łatwo komunikowalna i upowszechniona w postaci twardych danych, skodyfikowanych procedur czy uniwersalnych zasad. Jest ona nabywana w procesie uczenia się za pośrednictwem umysłu, przez: kształcenie, doświadczenie i trening.

Wiedza ukryta przede wszystkim wiąże się z podświadomością syntetyzowaną w umyśle stosownie do zapotrzebowania świadomości na podstawie wszelkich informacji zgromadzonych w procesie życiowym pod wpływem: nastawienia (stanu emocjonalnego, napięcia twórczego), przyswojonych ideałów i uznawanych wartości z udziałem intuicji. 


\section{Wiedza w umyśle człowieka}

RYSUNEK 2.

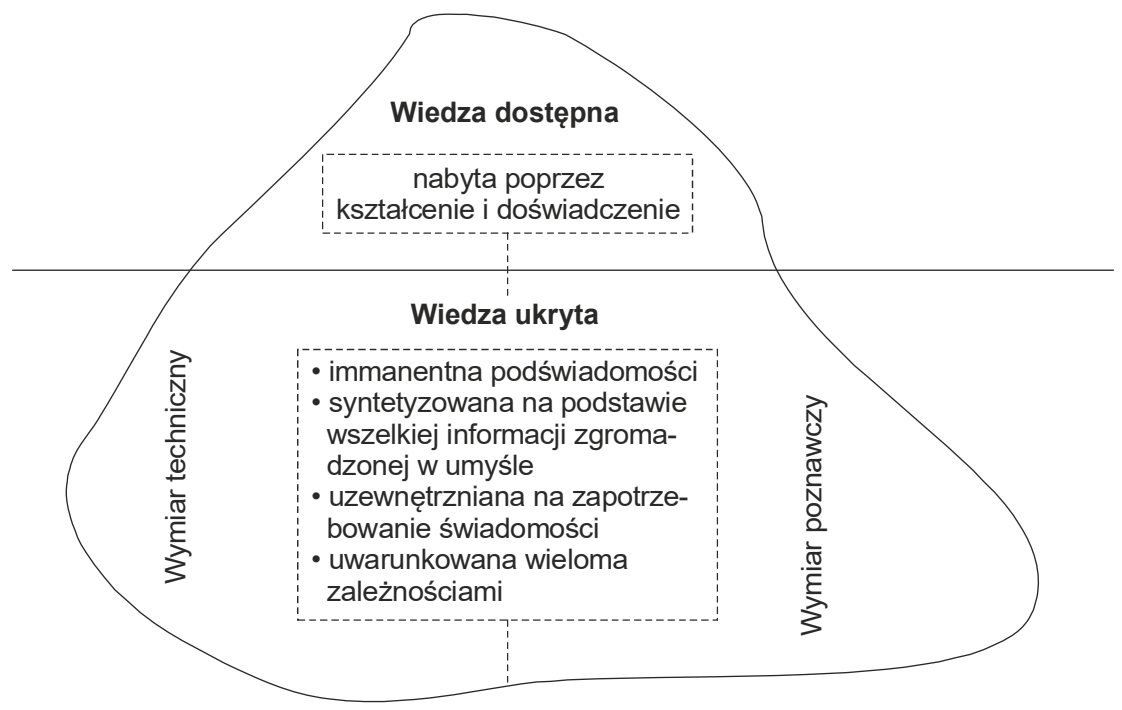

Źródło: [Poskrobko, 2011].

W działalności przedsiębiorstwa istotną rolę także odgrywa tzw. wiedza zespołowa. W teorii nauki o kreowaniu wiedzy przez pojęcie to rozumie się wiedzę indywidualna, która została powiększona i doprecyzowana w wyniku wspólnego działania zespołu, najczęściej za sprawą dyskusji i wspólnych doświadczeń jego członków. Nie jest ona jedynie prostą sumą wiedzy indywidualnej osób uczestniczących w pracy zespołu. Jest jednym z ważnych bodźców uruchomiania procesu twórczego, wykorzystania wiedzy ukrytej, przez co wzmacnia możliwości twórcze. Praca w zespole wpływa na powiększenie wiedzy indywidualnej - dostępnej i ukrytej - każdego członka zespołu (rysunek 3.).

Przez wiedzę organizacyjną w ujęciu teoretycznym rozumie się zwiększenie wiedzy indywidualnej w wyniku organizacyjnego zabezpieczenia pracy zespołów twórczych w organizacji. Służą temu takie działania, jak: zapewnienie dostępu do światowych baz danych, tworzenie warunków do oddolnego kreowania zespołów wiedzy zajmujących się rozwiązaniem konkretnych problemów, generowanie warunków do eksperymentowania. W ujęciu potocznym wiedza organizacyjna jest utożsamiana $z$ wiedzą organizacji. Wiedza ta może przejawiać się w dwojaki sposób, jako wiedza zespołowa i jako wiedza organizacji. 
RYSUNEK 3.

Przyrost wiedzy indywidualnej w wyniku pracy $\mathrm{w}$ zespole

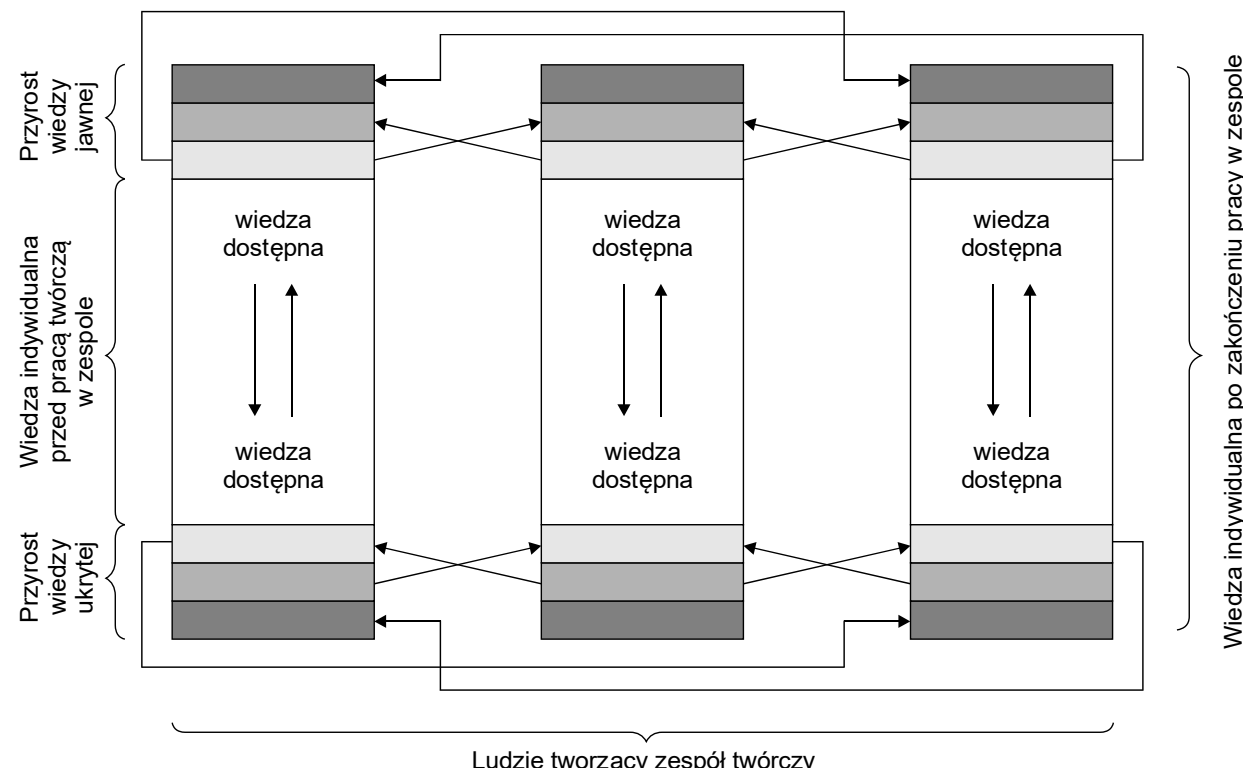

Źródło: [Poskrobko, 2011].

Wiedza organizacyjna nie ogranicza się jedynie do wiedzy zgromadzonej w umysłach pracowników, ale jest również utożsamiana z kulturą organizacyjną przejawiającą się w: zwyczajach, praktykach, sposobach postępowania, procedurach, kontaktach wewnętrznych i zewnętrznych oraz specyficznych normach i zasadach obowiązujących w organizacji. Ponadto, wiedza organizacyjna jest ściśle związana ze skodyfikowanymi zasobami informacyjnym organizacji [Kimble, 2013]. Zasoby te moga przybierać wielorakie formy, takie jak: dokumenty, opracowania i raporty, bazy danych itp.

\section{Kodyfikacja wiedzy w organizacji}

Kodyfikacja wiedzy to zebranie w jednolita, usystematyzowaną i opartą na wspólnych zasadach całość informacji (wiedzy) potrzebnych do funkcjonowania przedsiębiorstwa. Celem kodyfikacji wiedzy jest ułatwienie dostępu do zasobów wiedzy organizacji. Realizuje się to poprzez takie przetworzenie i usystematyzowanie posiadanych informacji, aby można je było łatwo odnaleźć, zrozumieć i przyswoić. Dane powinny być zapisane w określonym formacie, a dostęp do nich musi być możliwie prosty dla wszystkich upoważnionych do tego osób.

Rudy Ruggles [1997] traktuje kodyfikację jako formę reprezentacji wiedzy przede wszystkim służącą ponownemu użyciu przez pracowników indywidualnych bądź organizację. Proces ten ma na celu opracowanie zasobów wiedzy posiadanej przez firmę 
w formie przystępnej i nietrudnej do przenoszenia, zrozumiałej i łatwo dostępnej dla wszystkich. Jego głównym celem jest umożliwienie dostępu do wiedzy osobom, które w danym momencie jej potrzebuja, a także przekształcenie wiedzy cichej w zbiór uporządkowanych i ustrukturalizowanych informacji, tak by wiedza stała się łatwiejsza do: przekazywania, weryfikowania, magazynowania, reprodukowania, przeszukiwania, udostępniania oraz do sprzedaży.

Odpowiednio skodyfikowana i udostępniona wiedza może być narzędziem osiagania celów organizacji. Umiejętne zarządzanie wiedzą zgromadzoną w organizacji prowadzi do: kreowania przewagi konkurencyjnej, przyciagania i utrzymania klientów, budowania satysfakcji odbiorców, dostawców i innych interesariuszy, przyciagania potencjalnych partnerów, tworzenia wizerunku organizacji.

Do podstawowych zalet kodyfikacji wiedzy należą:

- $\quad$ przekształcenie wiedzy w towar - skodyfikowana wiedza zyskuje właściwości towaru, którym bezpośrednio można obracać na rynku, jak również wykorzystać w innych formach stosunków handlowych, takich jak wspólne przedsięwzięcia, relacje konsultantów lub strategiczne partnerstwa na rzecz rozwoju technologii;

- możliwość wykorzystania swoistych cech wiedzy - za sprawą kodyfikacji wiedzy jest możliwe wykorzystanie niektórych jej swoistych cech, w tym nierywalizacyjności (zasób wiedzy nie zmniejsza się na skutek jej sprzedaży) oraz niskiego krańcowego kosztu reprodukcji. Cechy te mogą znacząco obniżać koszty transferu technologii;

- modularyzacja wiedzy - kodyfikacja pozwala na łączenia w bloki (moduły) różnych rodzajów wiedzy znajdujących zastosowanie w takich samych lub zbliżonych do siebie procesach. Dzięki temu jest możliwe (w pewnym zakresie) wpływanie na tempo i kierunek generowania i dystrybucji wiedzy. Ponadto, posługiwanie się modułami wiedzy zabezpiecza przed kosztownym „odkrywaniem" przez inne zespoły tej samej organizacji rozwiazzań, badań oraz metod wcześniej wykorzystywanych w innych obszarach organizacji (np. w innych projektach) [Cohendet, Steinmueller, 2000].

Zasadniczy problem w procesie kodyfikacji wiedzy stanowi utrata jej wartości i cech wyróżniających oraz „degradowanie” wiedzy do informacji lub danych. Wśród badaczy długi czas panowało przekonanie, że diagramy i inne systemy zarządzania informacja odbierają wiedzy jej złożoność i bogactwo charakterystyczne dla systemów społecznych [Prusak, Davenport, 1998]. Jednak wydaje się, że wykorzystywane obecnie, coraz częściej zaawansowane, techniki informatyczne w pewnym stopniu są w stanie zniwelować lub choćby osłabić ten problem [Ikeda, Saito, Umemoto, 2007].

\section{Narzędzia i techniki informatyczne a kodyfikacja wiedzy}

Istotnym elementem w procesie zarządzania wiedza jest infrastruktura informatyczna. Generalnie można wyróżnić trzy obszary, w których wykorzystanie technologii informatycznych może w znacznej mierze wspierać proces kodyfikacji wiedzy, a mianowicie: 
- $\quad$ repozytoria wiedzy - systemy gromadzące i udostępniające informację, wchodząca w skład zasobu wiedzy, odpowiadające typowym strategiom kodyfikacji wiedzy. Do tej grupy należą: systemy zarządzania dokumentami, bazy danych, mechanizmy wyszukujące;

- $\quad$ katalogi ekspertów - systemy udostępniające ustrukturalizowane informacje, ułatwiające identyfikację i kontakt $z$ osobami posiadającymi potrzebną wiedzę, a przez to umożliwiające realizację strategii personalizacji wiedzy. Katalogi ekspertów to swoiste książki telefoniczne, zawierające informacje o profilach kompetencyjnych poszczególnych pracowników;

- narzędzia wspierające współpracę, ułatwiające wymianę wiedzy między pracownikami i personalizację wiedzy w organizacjach. Do tej grupy można zaliczyć: systemy pracy grupowej, pocztę elektroniczna, listy dyskusyjne, czat i komunikatory. Wprawdzie ta grupa rozwiązań jest związana ze strategia personalizacji, lecz dzięki możliwości archiwizacji kontaktów odbywających się za pośrednictwem systemów komputerowych jest także możliwa kodyfikacja wiedzy.

W ostatnich latach zdecydowanie największy rozwój zanotowały repozytoria wiedzy, choć pozostałe technologie, tj. katalogi ekspertów i narzędzia wspierające, również wzbogacily się o nowe możliwości. Po części jest to zasługa rewolucji i powstania nowych mediów (ang. digital media, social media). Repozytoria wiedzy wykorzystują nie tylko inteligentne sposoby agregacji, ekstrakcji i wnioskowania [Liu i in. 2017], ale zarazem rozszerzenia klasycznego repozytorium wiedzy opartego na relacyjnej bazie danych [Loia i in. 2013; Martinez, Pavlich-Mariscal, 2014; Jamil, 2009]. Ewolucja repozytoriów wiedzy stosuje głównie techniki sieciowe (grafowe) wsparte metadanymi. W wyniku temu, klasyczny silnik bazy wiedzy (ang. Content Management System - CMS) uległ transformacji w kierunku repozytorium z nowymi połaczeniami oraz kontekstem semantycznym, co umożliwia przechowywanie dodatkowych informacji w formie bardziej zrozumiałej dla człowieka. Jednocześnie powstaja systemy dedykowane, oparte na bazach wiedzy, które przyczyniają się do wsparcia określonych obszarów biznesowych działalności przedsiębiorstwa, organizacji, urzędu [Zhang, $\mathrm{Hu}, \mathrm{Xu}, 2011]$.

\subsection{Sposoby składowania wiedzy - technologie informatyczne}

Rozwiązania informatyczne, służące składowaniu i przetwarzaniu informacji mogą wykorzystywać narzędzia o różnym poziomie zaawansowania. Poczynając od prostych relacyjnych baz danych, dokumentowych czy grafowych, a na systemach automatycznego wnioskowania kończąc (ang. Decision Support Systems - DSS). Aby zastosować możliwości przetwarzania semantycznego, warto wykorzystać dodatkowo specjalizowane sposoby przechowywania informacji, takie jak np. grafowy model danych w reprezentacji wiedzy. Istnieją specjalne typy baz danych, które powstały po to, by usprawnić reprezentację ogromnych ilości powiązanych danych oraz zarzadzanie tymi danymi. Sa to bazy grafowe i sieciowe. Konstrukcje takich baz wykorzystuja struktury grafów ze specjalnie zdefiniowanymi węzłami (rysunek 4.). Można myśleć o węźle jako reprezentacji 
obiektu ze świata rzeczywistego, z krawędziami i własnościami do przedstawiania i przechowywania danych. Taka reprezentacja umożliwia także łatwiejszą implementację możliwości przeszukiwania bazy - w formie bardziej naturalnej dla człowieka - jako zapytań semantycznych [Loia i in. 2013; Martinez, Pavlich-Mariscal, 2014]. Wyszukiwanie semantyczne [Jamil, 2009] pozwala dostarczać wyniki nie tylko dzięki słowom kluczowym, ale przede wszystkim na podstawie automatycznej analizy relacji między słowami a wyrażeniami. Wszystko po to, żeby wyniki wyszukiwania były bardziej trafne i precyzyjne, po prostu mądrzejsze. Implementacją modelu grafowego w rzeczywistym świecie jest np. struktura hierarchiczna w firmie.

RYSUNEK 4.

\section{Graf zależności między ludźmi, systemami i informacjami}

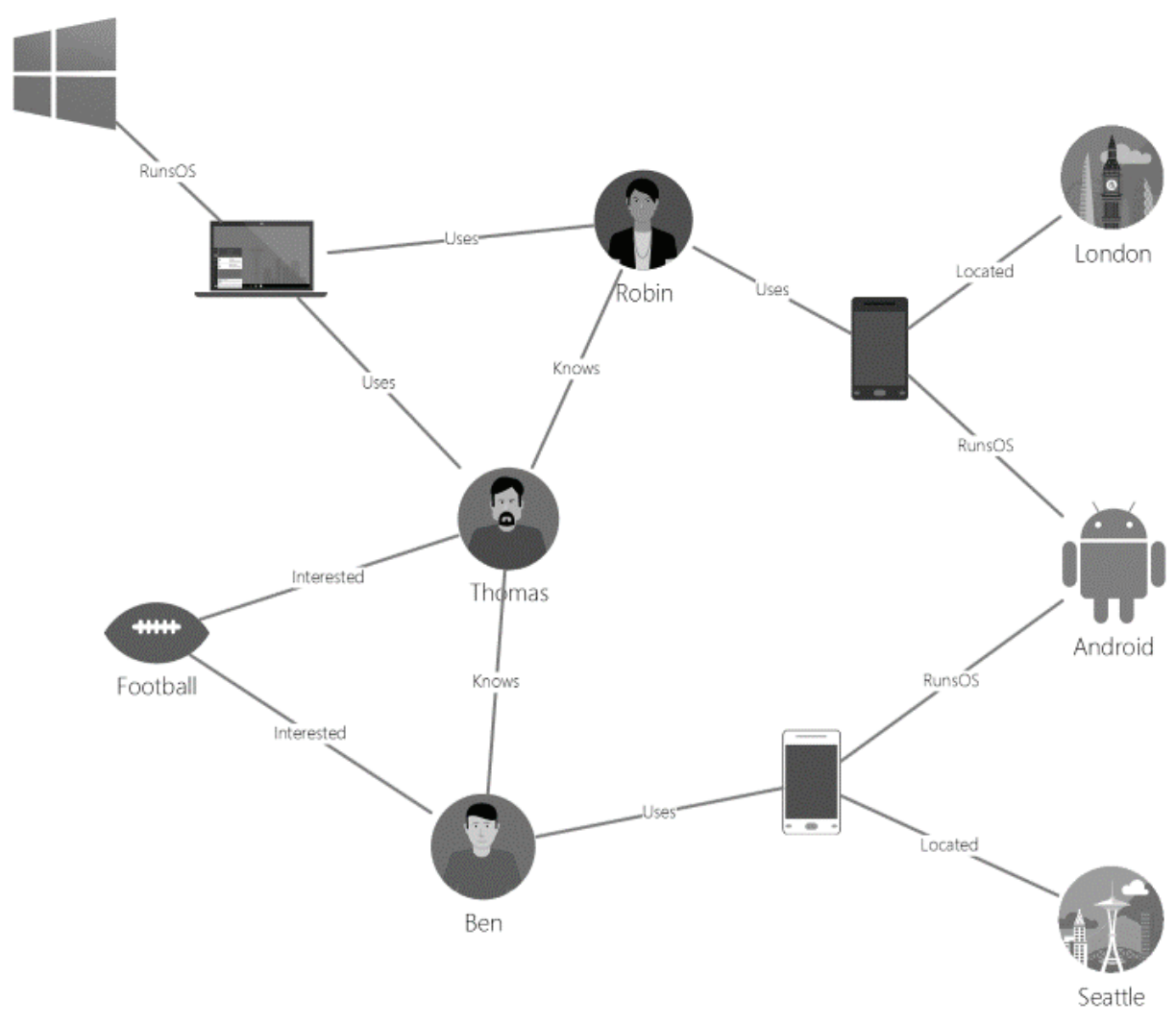

Źródło: Introduction to Azure Cosmos DB Graph APIs, Microsoft.

Inżynieria wiedzy dostarcza różnych metod reprezentacji wiedzy. W publikacjach naukowych z tego zakresu pojawiają się najczęściej takie pojęcia, takie jak: drzewa decyzyjne, scenariusze, reguły i sieci semantyczne. Należy przy tym zwrócić uwage na to, że bardzo istotnym elementem przetwarzania semantycznego jest dobrze zaprojek- 
towana ontologia [Hong, Yin, Chen, 2014]. To właśnie dzięki ontologii - czyli formalnej reprezentacji dziedziny wiedzy - jest generowany schemat pojęciowy, który nie tylko definiuje sposób opisu wiedzy, ale jednocześnie może służyć jako podstawa do automatycznego wnioskowania oraz budowy bardziej przyjaznego systemu zapytań, zbliżonego do zapytań w języku naturalnym [Liu i in. 2017; Jamil, 2009].

\subsection{Narzędzia przetwarzania}

Coraz częściej w procesach kodyfikacji wiedzy stosuje się inteligentne algorytmy, które, działając przy wykorzystaniu różnych narzędzi, pozwalają na półautomatyczne lub automatyczne pozyskiwanie, udostępnianie czy nawet wykorzystanie wiedzy (rysunek 5.). Do tych algorytmów także należą narzędzia coraz popularniejszej kategorii uczenia maszynowego (ang. machine learning). Każdy z tych algorytmów może być zaimplementowany na różnym poziomie zaawansowania, tj. zawierać mechanizmy, takie jak:

- $\quad$ automatycznego pozyskiwania wiedzy z danych - eksploracja danych (ang. Data Mining - DM) określana również pojęciem odkrywania wiedzy w bazach danych (ang. Knowledge Discovery in Databases - KDD);

- $\quad$ konwersji wiedzy w celu budowy reguł wnioskowania - conversion of knowledge from the case-based model to the rule-based representation;

- wyszukiwania semantycznego, o ile dysponuje się odpowiednimi metadanymi w bazie wiedzy;

- automatycznego wnioskowania na podstawie konkretnych przypadków (ang. case-based reasoning) czy reguł (ang. rule-based reasoning).

RYSUNEK 5.

Narzędzia informatyczne a model kształtowania wiedzy indywidualnej

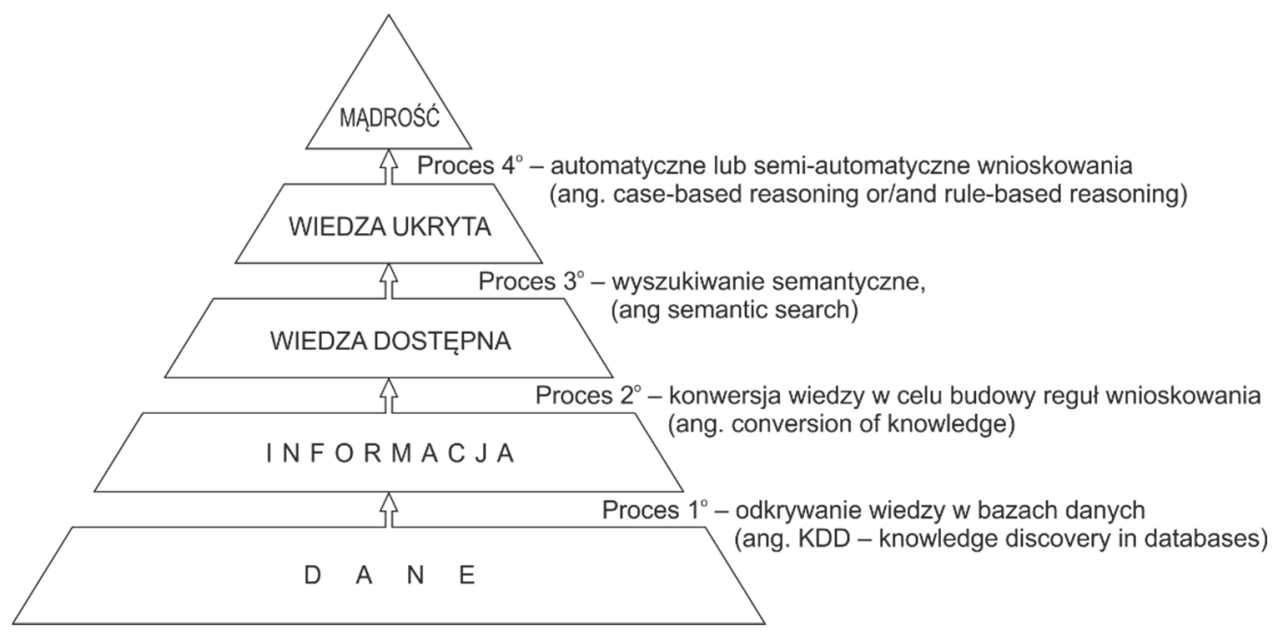

Źródło: opracowanie własne 
Nawet samo automatyczne wnioskowanie może odbywać się na różnym poziomie. Istnieją systemy, które pozwalają przygotować streszczenie materiałów tekstowych o objętości kilku lub kilkunastu stron, ale są zarazem systemy, które potrafią wyciagać wnioski z przetworzonego tekstu i samodzielnie formułować je w postaci kilku zdań [Avdeenko, Makarova, Klavsuts, 2016; Adamson, Campbell, Orsoni, 2005].

\subsection{Mechanizmy wspomagające użytkowanie}

Przez wiele lat jako narzędzie kodyfikacji wiedzy, a jednocześnie narzędzie wspomagające tworzenie i pozyskiwanie wiedzy znaczenia nabierały informatyczne systemy ekspertowe. Istota ich działania sprowadza się do wykorzystywania mechanizmów odpowiadających za przeprowadzanie konsultacji eksperckiej, a więc zastosowania metod wnioskowania dzięki posiadanym zasobom wiedzy. Innymi słowy, jest to system komputerowy, który emuluje proces podejmowania decyzji przez człowieka-eksperta. Systemy ekspertowe rozwiązuja złożone problemy na podstawie analizy baz wiedzy, a nie realizuja prostego algorytmu, jak to ma miejsce w przypadku programów tradycyjnych.

Obecnie prace naukowców skupiają się nad wykorzystaniem jeszcze bardziej zaawansowanych metod, które określa się w różny sposób, czasem mianem uczenia maszynowego [Khaled, Kechadi, Tari, 2011; Chen i in. 2011], innym razem systemów kognitywnych [Brggenwirth, Schulte, 2012; Zhu, Kong, Liu 2011] czy w końcu sztucznej inteligencji [Avdeenko, Makarova, Klavsuts, 2016; Adamson, Campbell, Orsoni, 2005]. W publikacji H. Khaleda i innych [2011] celem było zbadanie nowego rodzaju metod wyszukiwania opartych na systemie zarządzania wiedzą. Opracowano schematy transformacji wiedzy do przejściowej reprezentacji oraz nowe algorytmy wyszukiwania i wydobywania wiedzy, bazujące na tych reprezentacjach. Z kolei Y. Chen i inni [2011] zwrócili uwagę, że przy ogromnych ilościach danych, jakie są obecnie generowane $i$ archiwizowane, konieczne jest zastosowanie rozproszonych systemów wnioskowania z baz wiedzy (ang. distributed data mining). Przy okazji pokazali oni problem zarządzania wynikami procesu przetwarzania danych. Aby zmierzyć się z tym problemem, zbudowano specjalną architekturę, wykorzystując mapę ontologii wiedzy (ang. knowledge map ontology), która pozwala efektywniej reprezentować wiedzę i przedstawiać ją użytkownikowi.

Wynikiem prac Brggenwirth i Schulte [2012] jest propozycja kompleksowej architektury systemu, która składa się zarówno ze scentralizowanego modułu ontologii, jak i specyficznych dla problemu algorytmów - w formie inteligentnego frameworku. Algorytmy pozwalają nie tylko składować informacje, lecz jednocześnie przetwarzać je w kontekście procesów zorientowanych na cel (ang. goal-oriented), które są z kolei osadzone w kontekście sytuacyjnym (ang. situation interpretation).

Rozwiązanie według S. Zhu i innych [2011] skupia się na algorytmach zarządzania i wykorzystania wiedzy w sposób naśladujący procesy wnioskowania człowieka (ang. concept learning). Bazując na analizie najczęstszych zachowań dzieci, poznających otaczający 
je świat, zbudowano koncepcję kognitywnego modelu uczenia się. Zaimplementowane w ten sposób mechanizmy aktualizacji wiedzy rozszerzają standardową bazę wiedzy.

Jeszcze dalej posunęli się autorzy: Avdeenko, Makarova i Klavsuts [2016] oraz Adamson, Campbell i Orsoni [2005], którzy pokazali wyniki swoich badań w zakresie wykorzystania sztucznej inteligencji do automatycznego przetwarzania zarówno wiedzy, jak i budowania reguł wnioskowania. Koncepcja Avdeenko, Makarova i Klavsuts [2016] opiera się na transformacji wiedzy z modelu opartego na przypadkach (ang. casebased) do reprezentacji reguł wnioskowania (ang. rule-based). Natomiast, Adamson, Campbell i Orsoni [2005] w swojej pracy skoncentrowali się na przetwarzaniu wiedzy w sytuacji, kiedy brak jest sformalizowanych metodyk i opisanych procedur postępowania w konkretnych zdarzeniach. Na podstawie zebranych danych zaproponowali oni techniki odkrywania wiedzy (ang. knowledge discovery) jako narzędzia przetwarzania wstępnego do zbudowania systemu wsparcia podejmowania decyzji (ang. decision support system), wykorzystującego sztuczną inteligencję.

\section{Podsumowanie}

Zastosowanie narzędzi i technologii informatycznych w obszarze zarządzania wiedzą nabrało dużego tempa w ostatniej dekadzie. Jest to w szczególności zasługa coraz szerszych badań nad mechanizmami oraz narzędziami semi- $i$ automatycznych algorytmów przetwarzania danych, które wspieraja procesy kodyfikacji, a także zaawansowane sposoby wykorzystania wiedzy. Można sądzić, że będzie to jeden z głównych kierunków kolejnych badań w obszarze inteligentnych rozwiązań zarządzania wiedzą.

Problem z podejściem wykorzystującym inteligentne algorytmy kodyfikacji polega na złożoności jawnej i skodyfikowanej wiedzy o przedsiębiorstwie. Aby było możliwe wykorzystanie metod, które określa się mianem narzędzi sztucznej inteligencji, są potrzebne dodatkowe metadane - nie tylko topologii wiedzy i systemów grafowych, ale systemów ontologii. Jednak, aby w procesach kodyfikacji mogły być wykorzystywane zaawansowane narzędzia, konieczne jest wcześniejsze, dedykowane przetwarzanie danych i informacji z uwzględnieniem wymagań bardziej inteligentnych algorytmów. Prowadzone eksperymenty pokazuja, że obecnie naukowcy sa na etapie budowania systemów, w których coraz większą rolę odgrywają ontologie dziedzinowe, tworzone przy wsparciu automatycznych algorytmów ekstrakcji i klasyfikacji wiedzy.

Ontologie dziedzinowe zajmuja się wiedzą charakterystyczną dla ustalonej dziedziny lub z wybranego wycinka rzeczywistości. Dopiero, mając system zarządzania wiedzą zbudowany z wykorzystaniem odpowiednio dobranej ontologii, można pokusić się o wsparcie mechanizmów wykorzystania wiedzy poprzez narzędzia machine learningu czy sztucznej inteligencji. Sztuczna inteligencja daje niezadowalajace rezultaty w stosunku do danych, które reprezentują zbyt szeroki zakres tematyczny, są nieuporządkowane lub bardzo niekompletne.

Jednym z rozwiązań ułatwiających zastosowanie sztucznej inteligencji jest wykorzystanie, szeroko pojętej, inżynierii wiedzy, która obejmuje zarówno narzędzia przetwarzania i wykorzystania, jak i mechanizmy wstępnego przetwarzania, opracowania oraz 
transformacji danych i informacji. Jest to szczególnie ważne w obliczu nadchodzącego przełomu w procesie wykorzystania wiedzy przy użyciu systemów informatycznych. Aplikacje i serwisy internetowe zaczynają stosować inteligentne narzędzia wspomagania botów pomocy technicznej lub inteligentnych, wirtualnych asystentów. Te z kolei posiłkują się specjalizowanymi strukturami danych i informacji do precyzyjnego eksponowania treści wymaganych przez użytkownika w kontekście, w którym tego potrzebuje.

Przeprowadzona w niniejszej publikacji analiza stanu obecnej wiedzy w zakresie wykorzystania inteligentnych narzędzi informatycznych w procesach kodyfikacji wiedzy świadczy o tym, że doświadczenia z użyciem narzędzi sztucznej inteligencji praktycznie sa prowadzone na każdym etapie zarządzania wiedzą. Jak na razie, naukowcy dość ostrożnie podchodzą do wyników, w szczególności uczenia nienadzorowanego, lecz z pewnościa jest to problem zarówno naukowy, jak i aplikacyjny wymagający pogłębionej analizy. Zdaniem autorów, jest to również jeden z bardziej przyszłościowych kierunków rozwoju badań w obszarze nie tylko inżynierii wiedzy (nauki), ale także procesów kodyfikacji wiedzy (wykorzystania praktycznego).

\section{Wkład autorów w powstanie artykułu}

dr inż. Tomasz Poskrobko - opracowanie koncepcji, opracowanie części wstępnej, przeprowadzenie badań literaturowych i opracowanie wyników - 50\%

dr inż. Paweł Tadejko - opracowanie koncepcji, opracowanie części wstępnej, przeprowadzenie badań literaturowych i opracowanie wyników - 50\%

\section{Literatura}

Adamson K., Campbell P., Orsoni A., 2005, Hybrid Decision Support Based on Knowledge Discovery and AI Techniques for the Management of Maintenance Services in the Public Transport Sector, IEEE Intelligent Data Acquisition and Advanced Computing Systems, Technology and Applications, Sofia.

Avdeenko T., Makarova E., Klavsuts I., 2016, Artificial intelligence support of knowledge transformation in knowledge management systems, 13th International Scientific-Technical Conference on Actual Problems of Electronics Instrument Engineering (APEIE), Novosibirsk.

Bath S., 2000, Heeding the Sage of the Knowledge Age, CRM Magazine.

Brggenwirth S., Schulte A., 2012, COS A2 - A Cognitive System Architecture with Centralized Ontology and Specific Algorithms, IEEE International Conference on Systems, Man, and Cybernetics (SMC), Seoul.

Bukowitz W.R., Williams R.L., 1999, The Knowlegde Management Fieldbook, Pearson Education Limeted, London.

Chen Y., Wang Y., Ren H., Shi M., 2011, Research on Data Mining Method Based on Access Information for Knowledge Management System, International Conference on Management and Service Science, Wuhan. 
Cohendet P., Steinmueller W., 2000, The codification of knowledge: a conceptual and empirical exploration, "Industrial \& Corporate Change", vol. 9, no. 2.

Drucker P., 1994, The social age of transformation, "Atlantic Monthly", 274.

Gadomski A.M., 1993, TOGA: A Methodological and Conceptual Pattern for Modeling Abstract Intelligent Agent, First International Round-Table on Abstract Intelligent Agent, ENEA. Centro Ricerche Casaccia, Rome.

Girard J.L., Girard J.P., 2015, Defining knowledge management: Toward an applied compendium, "Online Journal of Applied Knowledge Management", vol. 3, no. 1.

Hong H., Yin Y., Chen X., 2014, Ontological Modelling of Knowledge Management for Human-Machine Integrated Design of Ultra-Precision Grinding Machine, Enterprise Systems Conference, Shanghai.

Ikeda M., Saito A., Umemoto K., 2007, A strategy-based ontology of knowledge management technologies, "Journal of Knowledge Management”, vol. 11.

Jamil H., 2009, A Novel Knowledge Representation Framework for Computing Sub-Graph Isomorphic Queries in Interaction Network Databases, 21st IEEE International Conference on Tools with Artificial Intelligence, Newark, NJ.

Khaled H., Kechadi T., Tari A., 2011, Ontology for knowledge management and improvement of data mining result, Proceedings 2011 IEEE International Conference on Spatial Data Mining and Geographical Knowledge Services, Fuzhou.

Kimble C., 2013, Knowledge Management, Codification and Tacit Knowledge, "Information Research: An International Electronic Journal", 18(2), 1-15, https:/ / files.eric.ed.gov/ fulltext/EJ1044669.pdf.

Kułak A., 2010, Zarzqdzanie wiedzq we wspótczesnym prz̨edsiębiorstwie, Wydawnictwo Wyższej Szkoły Ekonomii i Prawa im. prof. Edwarda Lipińskiego w Kielcach, Kielce.

Liu H., Xue L., ZhiWu L., Wu J., 2017, Linguistic Petri Nets Based on Cloud Model Theory for Knowledge Representation and Reasoning, "IEEE Transactions on Knowledge and Data Engineering", vol. PP, no. 99.

Loia V., Fenza G., De Maio C., Salerno S., 2013, Hybrid methodologies to foster ontologybased knowledge management platform, IEEE Symposium on Intelligent Agents (IA), Singapore.

Martinez S., Pavlich-Mariscal J., 2014, Formal design of a model repository based on knowledge representation using graphs, 9th Computing Colombian Conference (9CCC), Pereira.

Nonaka I., Takeuchi H., 1995, The knowledge-creating company: How Japanese companies create the dynamics of innovation, Oxford University Press, New York.

Pawłowski K., 2015, Medytacje platońskie. Rozważania filozofiçne na kanwie dialogów Platona, Wydawnictwo Uniwersytetu Kardynała Stefana Wyszyńskiego w Warszawie, Warszawa.

Poskrobko B., 2011, Wiedza i organizacja oparta na wiedzy, [w:] Gospodarka oparta na wiedzy - materialy do studiowania, B. Poskrobko (red.), Wyższa Szkoła Ekonomiczna w Białymstoku, Białystok.

Poskrobko T., 2015, Zarzqdzanie wiedzq jako instrument miekkeiego zarzqdzania, [w:] Wybrane zagadnienia miekekiego zarzadzania organizacjami, A. Kowalczewska (red.), EMENTON, Warszawa. 
Prusak L., Davenport T.H., 1998, Working Knowledge - How Organisations Manage What They Know, Harvard Business School Press, Boston.

Ruggles R., 1997, Knowledge Management Tools, Butterworth-Heinemann, Newton.

Sarvary M., 1999, Knowledge Management and Competition in the Consulting Industry, "California Management Review", iss. 2.

Senge P.M., 1999, The fifth discipline: the art and practice of the learning organization, Doubleday/Currency, New York.

Wiig K.M., 1993, Knowledge management Foundations: Thinking About Thinking - How People and Organizations Cerate, Represent, and Use Knowledge, Schema Press, Arlington, TH.

Zhang D., Hu D., Xu Y., 2011, Development of a process based product design knowledge reuse system, Eighth International Conference on Fuzzy Systems and Knowledge Discovery (FSKD), Shanghai.

Zhu S., Kong L., Liu J., 2011, Knowledge Management Method for Expert System Based on Cognitive Model, International Conference of Information Technology, Computer Engineering and Management Sciences, Nanjing, Jiangsu. 
